\title{
PELATIHAN IDENTIFIKASI dan STRATEGI MENGAJAR SISWA LAMBAN BELAJAR KEPADA GURU GURU YAYASAN WIJAYA KUSUMA TANGERANG
}

\author{
M Kusuma Wardhani
}

kusuma.wardhani@uph.edu

\begin{abstract}
Abstrak
Setiap anak dilahirkan berbeda satu dengan yang lain. Beberapa diantaranya dilahirkan dengan kondisi yang menempatkannya di luar kisaran perkembangan tipikal untuk usia mereka. Kondisi tersebut apabila tidak mendapatkan intervensi yang tepat, terutama dalam hal pendidikan, maka anak-anak ini tidak dapat mencapai potensi maksimalnya. Beberapa siswa di sekolah sekolah Yayasan Wijaya Kusuma mengalami keberbedaan tersebut, yang dapat dikategorikan sebagai siswa dengan kebutuhan khusus. Salah satu kebutuhan khusus tersebut adalah siswa lamban belajar, sehingga memerlukan intervensi berupa pengembangan strategi pembelajaran dan pengajaran yang disesuaikan. Permasalahannya adalah tidak semua guru di Yayasan Wijaya Kusuma mempunyai kemampuan tersebut. Pengabdian masyarakat diberikan di Yayasan ini dalam bentuk pelatihan berupa webinar, dengan tujuan memberikan pembekalan pada para guru untuk mempelajari cara identifikasi karakteristik siswa lamban belajar serta memberikan intervensi yang tepat bagi mereka. Metode pelaksanaan program dimulai dari rapat koordinasi dengan ketua Yayasan, berlanjut ke training need assessment, pengembangan materi pelatihan, pelaksanaan webinar, diakhiri dengan evaluasi serta tindak lanjut program. Program pelatihan ini memberikan hasil yang positif yaitu diantaranya para guru dapat mempelajari cara-cara mengidentifikasi karakteristik siswa lamban belajar, memberikan motivasi dan semangat baru untuk mengajar, serta mendapatkan inspirasi dalam
\end{abstract}

mengembangkan strategi pengajaran untuk siswa-siswa tersebut.

Kata kunci : lamban belajar, anak berkebutuhan khusus, identifikasi, intervensi

\section{PENDAHULUAN}

Pendidikan merupakan sebuah bekal bagi seorang anak, untuk dapat membentuknya menjadi pribadi yang utuh dan mumpuni, sehingga dapat berkontribusi maksimal bagi masyarakat. Menilik pada pentingnya pendidikan, maka pemerintah menetapkannya pada UU no 23 tahun 2002 pasal 9 ayat 1 , disebutkan bahwa setiap anak berhak memperoleh pendidikan dan pengajaran dalam rangka pengembangan pribadinya dan tingkat kecerdasannya sesuai dengan minat dan bakatnya. Kebijakan pemerintah ini berlaku untuk semua anak di seluruh daerah di Indonesia, tanpa memandang latar belakang maupun kondisinya.

Untuk melaksanakan amanah tersebut, salah satunya dengan mendirikan atau menyediakan sarana Lembaga pendidikan/sekolah. Ada suatu daerah di Tangerang Selatan, lebih tepatnya kelurahan Pondok Pucung, kecamatan Karang Tengah. Daerah ini merupakan penyangga yang memasok tenaga kerja yang bekerja di Jakarta maupun di perumahan2 terdekat. Penduduk yang tinggal disitu kebanyakan merupakan pekerja di Jakarta dan sekitarnya. Namun di daerah ini belum 
terdapat sekolah yang bisa menampung dan menyediakan pendidikan bagi anak-anak yang tinggal di daerah ini. Sampai pada suatu waktu, seorang tokoh masyarakat tergerak untuk mendirikan Lembaga pendidikan di lokasi ini.

Untuk memenuhi kebutuhan akan Pendidikan yang bermutu dan terjangkau maka pada tanggal 17 Nopember 1983 didirikan Yayasan Wijaya Kusuma Pratama sebagai Yayasan Pendidikan yang bersifat Nasional. Sekolah Wijaya Kusuma Pratama berlokasi di Jl Dahlia A/100, Pondok Pucung Indah 1, Pondok Aren, Tangerang Selatan 15429. Lokasi tersebut terletak di antara daerah Bintaro dan Bumi Serpong Damai.

Bermula dari 1 kelas TK dengan murid 13 orang sekarang Sekolah Wijaya Kusuma Pratama telah mempunyai TK, SD dan SMP dengan murid sekitar 450 orang dan tenaga guru sekitar 40 orang. Masing2 tingkat terdiri atas dua kelas. Motto Yayasan Wijaya Kusuma Pratama adalah untuk "Menyediakan Sekolah Bermutu dan Terjangkau" dan Pendidikan yang diberikan bersifat Nasional, tersedia untuk semua agama. Pada saat ini sekitar $60 \%$ murid beragama muslim, 37\% Kristen dan Katolik, dan 3\% lain-lain seperti Khonghucu, Hindu Bali, dan seterusnya. Latar belakang guru sangat bervariasi, ada 3 guru Kristen yang juga menjadi klerik/aktifis gereja dan banyak guru berlatar belakang muslim juga.

Orang tua murid kebanyakan merupakan pekerja di Jakarta dan sekitarnya, namun demikian Sekolah Wijaya Kusuma Pratama juga menampung dari penduduk sekitar. Kebijakan keuangan Yayasan Wijaya Kusuma Pratama adalah subsidi silang, dari 450 orang sekitar 100 murid mendapatkan subsidi. Uang sekolah yang relatif murah untuk ukuran daerah (SPP berkisar Rp 500.000,- sampai Rp 0,-) menyebabkan banyak orang tua yang kebanyakan berprofesi sebagai asisten rumah tangga sampai ke pekerja apartemen di sekitar wilayah tersebut, mempercayakan anaknya masuk ke Sekolah Wijaya Kusuma Pratama.

Beragamnya kondisi ekonomi dan pendidikan orang tua dan karena kebanyakan orang tua keduanya bekerja menyebabkan berbagai persoalan timbul dalam kegiatan belajar mengajar. Beberapa hal yang dirasakan antara lain adalah adanya murid yang mempunyai "kesulitan" dalam belajar. Apabila kesulitan-nya disebabkan karena fasilitas, sekolah masih bisa menangani dengan membuka sekolah s/d jam 4 sore. Namun kesulitan di alami ketika ada hambatan fisiologis maupun psikologis seperti "intellectual disability", autism, dyslexia, ADHD dan lain-lain. Bila kasusnya berat pada umumnya Sekolah Wijaya Kusuma menyarankan untuk disekolahkan di sekolah khusus. Namun demikian banyak yang bersifat "border case" yang oleh dokter dianjurkan untuk bersekolah di sekolah umum/ sekolah iklusi. Permasalahan terjadi karena siswa siswa tersebut tergolong ke dalam anak yang berkebutuhan khusus, sehingga memerlukan cara mengajar yang berbeda pula dengan siswa mormal pada umumnya.

Siswa dengan kebutuhan khusus adalah anak dengan tumbuh kembang yang berbeda dari ratarata anak normal, dipandang dari aspek mental, sosial, maupun fisiknya (Efendi,2006 dalam Wardhani,M.K, 2019)

Padahal tidak semua guru guru mempunyai pengetahuan untuk mengidentifikasi anak berkebutuhan khusus di dalam kelasnya, yang apabila memang ada, maka memerlukan pula penerapan strategi belajar yang berbeda dengan siswa pada umunya. Di samping itu karena beragamnya orangtua murid di sekitar perumahan maka guru-guru juga menjadi tempat untuk bertanya bilamana anak mereka mempunyai "kesulitan belajar".

Oleh karena itu, maka pelatihan tentang pendidikan untuk anak berkebutuhan khusus dalam konteks sekolah inklusi menjadi sebuah urgensi bagi para pendidik di sekolah ini. Kebutuhan dari Yayasan ini adalah pengenalan /identifikasi dari siswa-siswa berkebutuhan khusus dan penerapan strategi belajar mengajar yang tepat sesuai dengan kekhususan siswa. Beberapa jenis kekhususan siswa yang ada di sekolah ini adalah siswa lamban belajar, ADHD, serta autisme ringan.

Berangkat dari kebutuhan tersebut, maka Universitas Pelita Harapan melalui Fakultas Pendidikan/ Teachers College, yang diwakili oleh dosen dan beberapa mahasiswa, melaksanakan program pengabdian masyarakat di Yayasan Wijaya Kusuma. Setelah melalui tahapan analisa kebutuhan pelatihan, maka diputuskan bahwa prioritas target pelatihan adalah para guru yang memiliki siswa didik dengan kebutuhan khusus lamban belajar atau biasa disebut dengan istilah slow learner. Siswa lamban belajar ini adalah siswa dengan nilai tingkat 
kecerdasan (Intelligence Quotients) dibawah anak normal, yang berdampak pada rendahnya tingkat keberhasilan studinya (Mahastuti, 2011). Namun meskipun begitu, siswa lamban belajar ini tidak bisa dimasukkan ke dalam golongan anak tuna grahita ( down syndrome), karena skor IQ nya antara 70-90 (Amalia,2019), sedangkan tuna grahita skor IQ nya dibawah 70.

Dari uraian di atas, maka dapat disimpulkan bahwa permasalahan dari sekolah Yayasan Wijaya Kusuma adalah adanya siswa-siswa dengan kebutuhan khusus lamban belajar, yang membutuhkan pelayanan pembelajaran dengan penyesuaian strategi pengajaran. Namun guru guru di sekolah tersebut, belum mempunyai kompetensi tersebut.

Sehingga rencana penanganan masalah yang diberikan melalui kegiatan pengabdian mayarakat ini adalah, memberikan pelatihan dalam bentuk webinar, dengan topik pembekalan mengenai pengenalan /identifikasi dari siswa lamban belajar dan bagaimana merancang strategi pengajaran

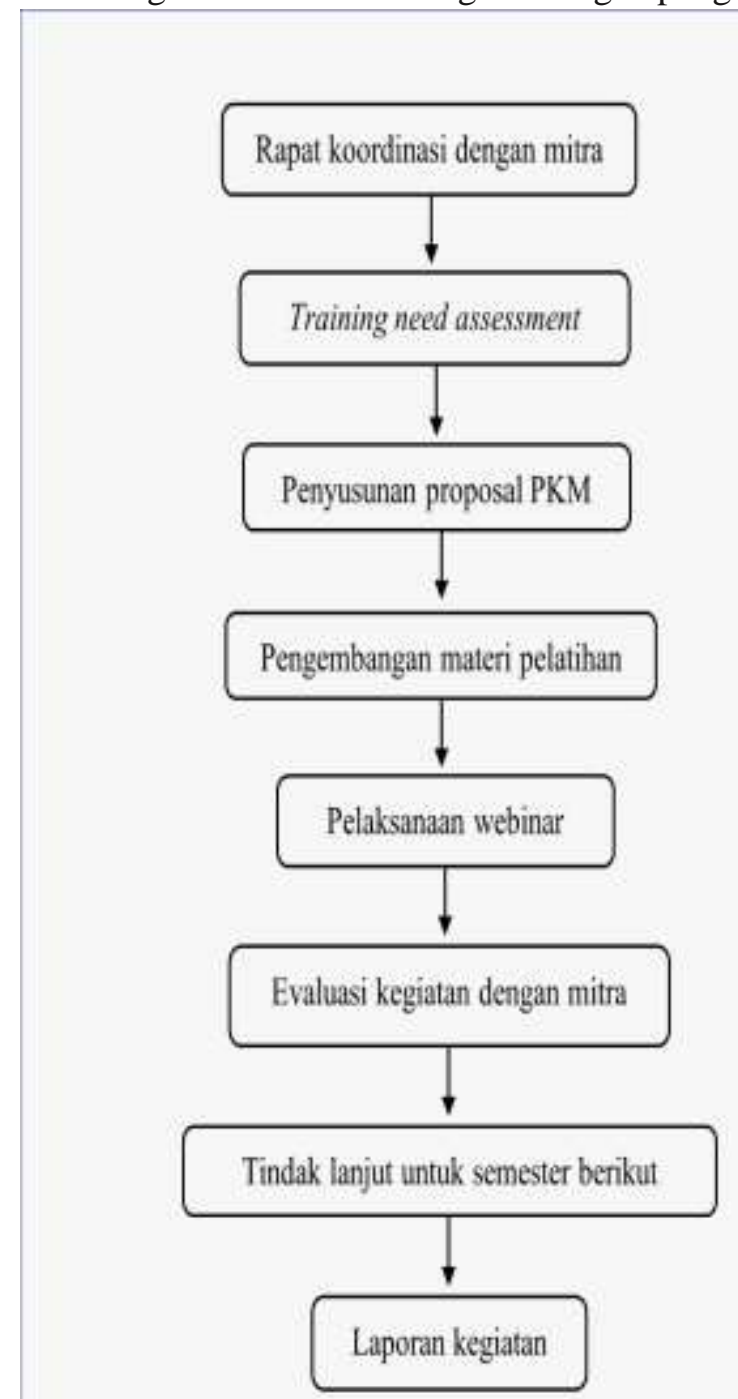

untuk siswa-siswa tersebut.

\section{METODE}

Langkah-langkah pelaksaannya dari kegiatan pengabdian masyarakat di Yayasan Wijaya Kusuma dapat dilihat dalam bagan berikut ini:

Gambar 1 : Langkah-langkah pelaksanaan kegiatan PkM

Inisiasi pertemuan pertama, berupa rapat koordinasi dengan pimpinan Yayasan, pada bulan Januari 2021. Pertemuan dihadiri oleh pimpinan Yayasan, kepala sekolah, serta beberapa dosen fakultas pendidikan Universitas Pelita Harapan. Langkah kedua adalah melaksanakan Analisa kebutuhan pelatihan . Adman (2005) dalam jurnalnya memaparkan bahwa analisa kebutuhan pelatihan dideskripsikan sebagai ; metode analisa data dengan tujuan mengenali bidang atau faktor apa saja yang perlu ditingkatkan agar produktifitas atau kinerja dari pekerja akan meningkat. Sehingga setelah dilakukan analisa akan dapat diketahui, apakah ada kebutuhan akan pelatihan dan apa materi yang menjadi kebutuhannya. Metode yang dipakai untuk kegiatan ini adalah wawancara, yang dilakukan pada pimpinan Yayasan, kepala sekolah, serta perwakilan bagian kurikulum sekolah.

Setelah diketahui apa yang menjadi materi pelatihan, maka disusunlah proposal yang menggambarkan analisa situasi, permasalahan mitra, solusi yang ditawarkan, jadwal serta budget program. Pengembangan materi dilaksanakan dengan kedalaman dan keluasan materi berdasarkan hasil wawancara dengan pihak sekolah. Pelaksanaan kegiatan pengabdian masayarakat di Yayasan Wijaya Kusuma dimulai dari bulan Januari sampai dengan Juni 2021, yang dilaksanakan dalam beberapa topik pelatihan. Sedangkan untuk topik pelatihan siswa lamban belajar dilaksanakan pada bulan Mei 2021. Jumlah peserta 36 guru yang terdiri dari guru PAUD, SD, SMP dan SMA. Lama mengajar para guru ini bervariasi dari mulai 2 sampai 10 tahun. Setelah kegiatan dilaksanakan, dilakukan evaluasi dan rencana tindak lanjut pelatihan untuk semester depan. Dalam pelaksanaan kegiatan pengabdian masyarakat ini, beberapa mahasiswa fakultas pendidikan ikut terlibat 
didalamnya. Tugas yang mereka kerjakan antara lain adalah merapikan presentasi dari dosen pemateri, membuat link google form untuk pre-test dan post-test, serta membantu mengolah data kuestioner.

\section{JADWAL PELAKSANAAN KEGIATAN}

\begin{tabular}{|c|c|c|c|c|c|c|c|}
\hline \multirow{2}{*}{ No } & \multirow{2}{*}{ Nama Kegiatan } & \multicolumn{6}{|c|}{ Bulan } \\
\hline & & 1 & 2 & 3 & 4 & 5 & 6 \\
\hline 1 & Rapat koordinasi dengan mitra & & & & & & \\
\hline 2 & Training need assessment & & & & & & \\
\hline 3 & Peayusunan proposal PKM & & & & & & \\
\hline 4 & Pengembangan materi pelatihan & & & & & & \\
\hline 5 & Pelaksanaan webinar & & & & & & \\
\hline 6 & Evaluasi kegiatan & & & & & & \\
\hline 7 & Tindak lanjut kegiatan semester depan & & & & & & \\
\hline 8 & Laporan kegiatan & & & & & & \\
\hline
\end{tabular}

Tabel 1 : Jadwal pelaksanaan kegiatan pelatihan

\section{HASIL DAN PEMBAHASAN}

\section{Materi Pelatihan}

Judul dari pelatihan yang diberikan adalah Siswa Lamban Belajar, Siapakah Mereka dan Bagaimana Caranya Menolong Mereka. Materi yang menjadi kebutuhan guru-guru adalah pengertian atau deskripsi serta karakteristik dari siswa lamban belajar, apa yang menjadi permasalahan siswa tersebut dalam pembelajarannya, bagaimana cara pengamatan guru untuk melakukan identifikasi, serta mengembangkan strategi pengajaran yang tepat. Selain itu juga bagaimana memotivasi siswa dengan gangguan belajar ini, agar tetap semangat belajar.

2. Materi Identifikasi Ciri dan Karakteristik Siswa Lamban Belajar

Sebelum pelatihan, para guru peserta diberikan dua pertanyaan yaitu 1) Siapakah siswa lamban belajar menurut guru, 2) Apakah guru mempunyai siswa lamban belajar dalam kelas yang diajar, dan jika ada bagaimana ciri- cirinya yang nampak di dalam kelas. Ringkasan jawaban dari peserta untuk pertanyaan deskripsi siswa lamban belajar adalah a) Anak yang mempunyai skor IQ dibawah rata-rata normal dan mempunyai tingkat keberhasilan relatif rendah pada tugas sekolah; b) Anak dengan tingkat penguasaan materi yang rendah ; c) Anak anak yang mempunyai kemampuan relatif rendah pada tugas yang diberikan ; d) Murid yang sulit dan lama menerima pembelajaran ; e) Murid yang memiliki daya tangkap yang lemah dan memiliki tingkat kecedasan yang rendah ; f) Siswa yang lambat dalam proses belajar, sehingga ia membutuhkan waktu yang lebih lama dibandingkan sekelompok siswa lain yang memiliki taraf potensi intelektual yang sama; g) Siswa yang tidak bisa mengikuti alur belajar yg disampaikan oleh guru ; h) Murid yang ketika diperintah untuk disiplin waktu dan mengerjakan tugas praktek, selalu menunda pekerjaannya ; i)Siswa yang membutuhkan waktu cukup lama untuk menyelesaikan tugas yang diberikan.

Selanjutnya ciri-ciri yang ditampakkan di dalam kelas, jabaran jawabannya sebegai berikut : a) Rendahnya tingkat keberhasilan pada tugas sekolah ; b) Sering terlihat bengong atau melamun ; c) Tidak konsentrasi ;

d) Lamban dalam memahami materi yang diajarkan, sulit mencapai nilai yang diharapkan ; e) perkembangan mental, intelektual, sosial, ekonomi, kepribadian dan proses-proses belajar yang dilakukannya di sekolah dan di rumah ; f) tidak fokus ketika mendengarkan penjelasan guru ; g) tidak bisa mengikuti pembelajaran kelompok; h) tidak bisa memahami soal ; i) sulit mengikuti proses kegiatan belajar mengajar ; j) pada umumnya pendiam.

Jawaban para peserta tadi sudah sesuai dengan teori-teori yang menjelaskan mengenai deskripsi dan ciri-ciri dari siswa lamban belajar.

Amdany, Sularmi, \& Sriyanto,(2018), menulis bahwa siswa lamban belajar berada pada level IQ 70-90, yang artinya di bawah IQ siswa normal. Anak-anak ini akan mempunyai hambatan dalam hampir semua mata pelajaran, khususnya yang berhubungan dengan hafalan, secara psikologis mereka juga cenderung memiliki perasaan minder, pemalu, tidak mau berbaur dengan lingkungannya, lambat dalam memproses informasi, dan seringkali teman sebayanya memperlakukan dengan kurang baik (Wati, 2018). Dampak dari level IQ dibawah 
rata-rata, menyebabkan tingkat pencapaian keberhasilan yang rendah pada tugas tugas sekolahnya. Jika merunut penyebab dari kebutuhan khusus ini ada lima kategori yaitu, penyebab bawaan/ genetic, sebelum kelahiran, sewaktu kelahiran, sstelah kelahiran, dan juga dari lingkungan (Mahastuti, 2011). Anak-anak spesial ini juga mempunyai beberapa ciri antara lain ; emosional dan sensitif, menyukai tugas-tugas sederhana dan merasa stress dibawah situasi yang kompleks, memiliki jangka fokus yang singkat dan sangat cepat kehilangan konsentrasi , menyukai bekerja dalam kecepatan mereka sendiri dan bukan dalam waktu yang dibatasi, tidak tertarik dalam keterampilan menghafal massal yang mana naturnya sangatlah akademis (Madtha,J.L, 2021)

\section{Rencana Pelaksanaan Strategi Pengajaran}

Setelah sesi pelatihan berakhir, peserta diberikan dua pertanyaan; setelah mendapatkan pemahaman mengenai deskripsi, ciri-ciri, cara mengidentifikasi, dan juga mengembangkan strategi pengajaran, maka 1) apakah startegi yang akan diterapkan para guru sebagai tindak lanjut pelatihan, dan juga 2) apakah hal baru yang dipelajari dan apa manfaatnya bagi proses belajar mengajar selanjutnya. Berikut ini adalah ringkasan strategi yang akan diterapkan oleh para guru peserta pelatihan ; a) mencoba mengaplikasikan pembelajaran hari ini ; b) menganalisis siswa dan menerapkan strategi belajar untuk setiap siswa sehingga tujuan belajar itu tercapai; c) lebih memperhatikan anak slow learner dan berkebutuhan khusus serta sabar dan selalu mencari cara baru untuk memberikan pembelajaran efektif bagi mereka ; d) mengulang materi yg diajarkan, memberikan waktu penyelesaian yg berbeda dari anak yang memang cepat dalam menerima pelajaran ; e) memberikan pendampingan dalam menyelesaikan latihan/tugas yang diberikan ; f) memberikan latihan/tugas sesuai kemampuan bagi anak yang slow learner ; g) tidak bosan membimbing dan bekerja sama serta mengajak untuk konsultasi psikolog ; h) memberi kesempatan lebih banyak dibanding siswa lain ; i) memberikan tugas yang lebih sederhana dibandingkan siswa yg sebayanya, memberikan pengulangan materi bagi siswa yang slow learner ; j) memberikan perhatian khusus, pada anak tersebut, jika perlu memberikan tambahan jam belajar ; k) mendiskusikan dengan orangtua siswa, supaya orangtua bisa menjadi partner guru dalam membimbing siswa.
Rencana strategi yang hendak diterapkan para guru tersebut, adalah strategi-strategi yang juga disarankan dalam beberapa jurnal ilmiah .

Utami,N.E. (2018) memaparkan dalam sebuah strategi rangkaian kegiatan belajar mengajar :

Didalam setiap sesi pembelajaran, guru memulainya dengan memaparkan kembali materi yang diajarkan minggu lalu, dan menjelaskan kaitannya, dalam pengajarannya guru menggunakan bahasa yang sederhana sehingga mudah dimengerti, memberikan pengulangan materi pelajaran bagi siswa lamban belajar, tugas yang diberikan sesuai dengan kemampuannya, dengan tingkat kesulitan lebih rendah dan jumlah lebih sedikit dibanding siswa yang normal, di dalam menjelaskan konsep guru memberikan pemahaman, bukan menghafal konsep , karena siswa lamban sangat lemah di dalam menghafal, selalu memberikan motivasi belajar supaya siswa tidak putus asa, melibatkan orangtua sebagai partner guru, untuk membantu siswa ketika berada di rumah, dengan memberikan bimbingan ataupun pelatihan, juga mengadakan pertemuan dengan orangtua untuk membahas perkembangan pendidikan siswa lamban belajar.

Khabibah, N. (2017) menambahkan beberapa strategi ; Siswa diberikan tambahan jam pelajaran untuk mengejar ketinggalannya, melatih indra siswa lamban belajar sesuai dengan gaya belajarnya, apakah kinestatik, visual atau auditori. Memberikan motivasi pada siswa dengan membuat anak merasa gembira atas keberhasilannya, walaupun hanya mengalamai sedikit kemajuan, sehingga anak akan terus punya motivasi untuk berusaha. Guru perlu memahami bahwa motivasi ini penting untuk terus diberikan pada siswa siswa ini , karena jika mereka masih mempunyai motivasi ,maka siswa siswa ini akan tetap mau melakukan usaha dan mencapai kemajuan demi kemajuan dalam pendidikannya.

\section{Manfaat Pelatihan}

Sebagai evaluasi bagi kegiatan pengabdian ini, maka peserta diberikan kuestioner untuk memberikan pendapatnya, apa manfaat yang didapat dari pelatihan ini. Berikut adalah sejumlah manfaat yag diperoleh peserta : 1) mempelajari bagaimana menghadapi dan memotivasi murid slow learner ; 2) mendapatkan info info menarik tentang materi lamban belajar ; 3) mempelajari strategi 
pembelajaran menangani siswa yang lamban belajar ; 4) informasi tentang ciri dan karakteristik tentang lamban belajar ; 5) memahami bahwa anak lamban belajar juga bisa ditolong dengan memaksimalkan potensinya ; 6) menjelaskan ciri ciri slow learner dan tuna grahita. cara identifikasi dan solusi ketika memberikan pelajaran ; 7) memahami perlunya perhatian khusus pada anak yang lamban ; 8) dapat mengidentifikasi kebutuhan khusus siswa ; 9) mempelajari cara penanganan siswa yang mengalami slow learner ; 10) banyak hal yang didapat, diantaranya bagaimana cara mengidentifikasi siswa slow learner dan bagaimana strategi mengajar terhadap siswa yang slow learner ; 11) mengidentifikasi secara dini karakteristik slow learner dari faktor-faktor kogntif, afektif dan sosial ; 12) memahami bahwa dalam menangani siswa lamban kita sebagai guru perlu lebih sabar dan kreatif ; 13) dalam menyampaikan materi terutama kejelasan materi dan alokasi waktu disesuaikan dengan memperhatikan kondisi kognitif dan afektif siswa tersebut sehingga apa yang disampaikan guru dapat dipahami oleh siswa ; 14) mendapatkan pengetahuan tentang anak yang lamban belajar, tidak harus belajar pada csekolah luar biasa, tapi bisa di sekolah inklusi ; 15) memahami peran guru dalam menolong anak yang lamban belajar agar tidak minder dan dapat memotivasi agar bisa semangat belajar ; 16) memberikan inspirasi dan motivasi baru dalam mengajar.

\section{KESIMPULAN}

Kegiatan pengabdian masyarakat dosen fakultas pendidikan Universitas Pelita Harapan yang bekerjasama dengan Yayasan Wijaya Kusuma mendapatkan sambutan yang sangat baik dari para guru yang mengikuti pelatihan berupa webinar. Mereka menyatakan bahwa ada banyak manfaat yang diperoleh. Setelah mendapatkan pelatihan, para guru mendapatkan pemahaman tentang siswa lamban belajar dan dapat merancang strategi pembelajaran yang sesuai dengan kebutuhan siswasiswa tersebut.

Pihak sekolah dan dosen sepakat untuk dilanjutkan di semester berikutnya. Ada beberapa saran yang diberikan oleh peserta, apabila pelatihan ini diselenggarakan lagi. Adapun saran-saran tersebut adalah ; para guru berharap jika pelatihan tidak hanya dilakukan secara online berupa webinar, namun juga ada pertemuan luring, menambah waktu pelatihan karena 2 jam dirasa masih kurang, orang-tua siswa perlu diikutserta kan juga sebagai peserta pelatihan.

\section{UCAPAN TERIMAKASIH}

Ucapan terimakasih disampaikan kepada Lembaga Penelitian dan Pengabdian kepada Masyarakat Universitas Pelita Harapan, yang telah memberikan pengarahan, perijinan untuk keberlangsungan kegiatan pengabdian masyarakat ini. Adapun dokumen yang diajukan terkait kegiatan ini adalah proposal dan laporan dengan nomor PM-213-M/FIP/XII/2020

\section{REFERENSI}

Adman. (2005). Analisa Kebutuhan Pelatihan Pegawai pada Prodi Manajemen Perkantoran UPI. Jurnal Manajemen dan Sistem Informasi.

Amdany, Sularmi, \& Sriyanto (2018) Learning Motivation of Slow Learner in Elementary School. Jurnal Universitas Sebelas Maret. https://jurnal.uns.ac.id/SHES/article/view/23506

Khabibah, N. (2017). Penanganan Instruksional Bagi Anak Lambat Belajar (Slow Learner). Jurnal Didaktika

http://journal.umg.ac.id/index.php/didaktika/article/ view/41/29

Madtha, J. L. (2015). Motivation and Encouragement in Teaching Slow Learners. International Journal of Current Research, 7(04): 14643-14644.

Kurniati. (2019). Upaya Guru Dalam Membimbing Anak Lamban Belajar (Slow Learner) Di MIN 03 Rejang Lebong. Doctoral dissertation, IAIN Curup. 


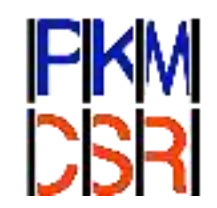

Malia. (2019). Analisis problematika Pembelajaran Guru Pembimbing Khusus (GPK) Dalam Menangani Siswa Lamban Belajar (Slow Learner) di SDN Sumbersari 2 Malang.

Utami,N.E. (2018) Layanan Guru Kelas Bagi Siswa Slow Learner di Sekolah Inklusi (SD N Bangunrejo 2 Yogyakarta) Jurnal Pendidikan Dasar Islam

https://media.neliti.com/media/publications/284567 -layanan-guru-kelas-bagi-siswa-slow-learn3bb177e8.pdf

Wardhani, M. K. (2020). Persepsi dan Kesiapan Mengajar Mahasiswa Guru Terhadap Anak Berkebutuhan Khusus dalam Konteks Sekolah Inklusi. Jurnal Pendidikan dan Kebudayaan.

https://ejournal.uksw.edu/scholaria/article/view/338 $\underline{2 / 1445}$

Zalukhu, J. T. (2020). Strategi Guru Dalam Menangani Pelajar Lamban/Lamban Belajar (Slow Learner). Doctoral dissertation, Sekolah Tinggi Teologi Injili Arastamar (SETIA) Jakarta.

Mahastuti, D. (2011). Mengenal Lebih Dekat Anak Lambat Belajar. Jurnal Ilmu Psikologi, 42.

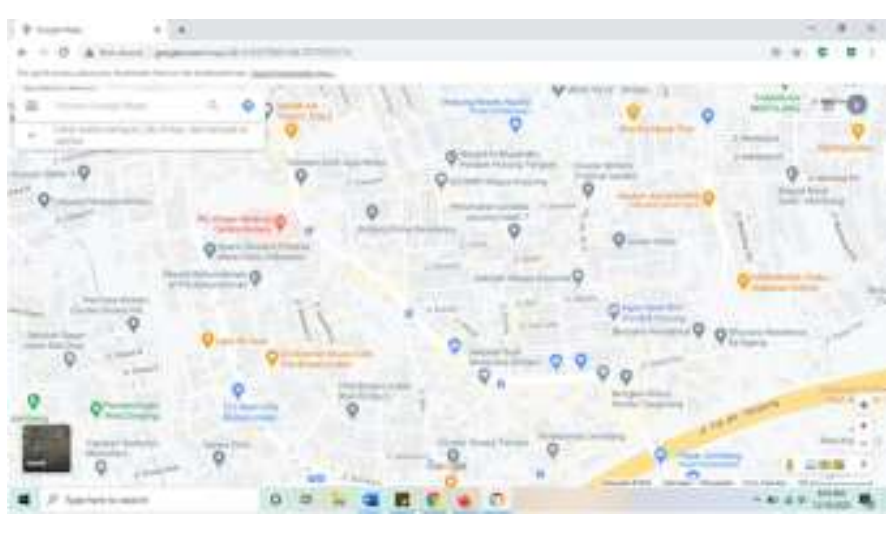

\section{PETA LOKASI MITRA SASARAN}

Sekolah Wijaya Kusuma Pratama berlokasi di Jl Dahlia A/100, Pondok Pucung Indah 1, Pondok Aren, Tangerang Selatan 15429.

Lokasi tersebut terletak di antara daerah Bintaro dan Bumi Serpong Damai.

Googlemaplink https://goo.gl/maps/71jmk7LyLE1U4wP78

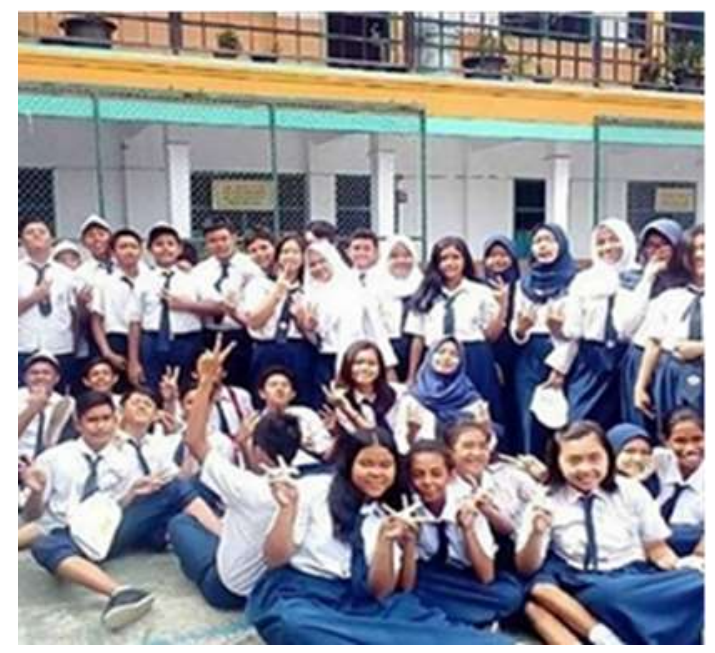

Siswa siswa Sekolah Wijaya Kusuma 


\section{FF|M CBR}
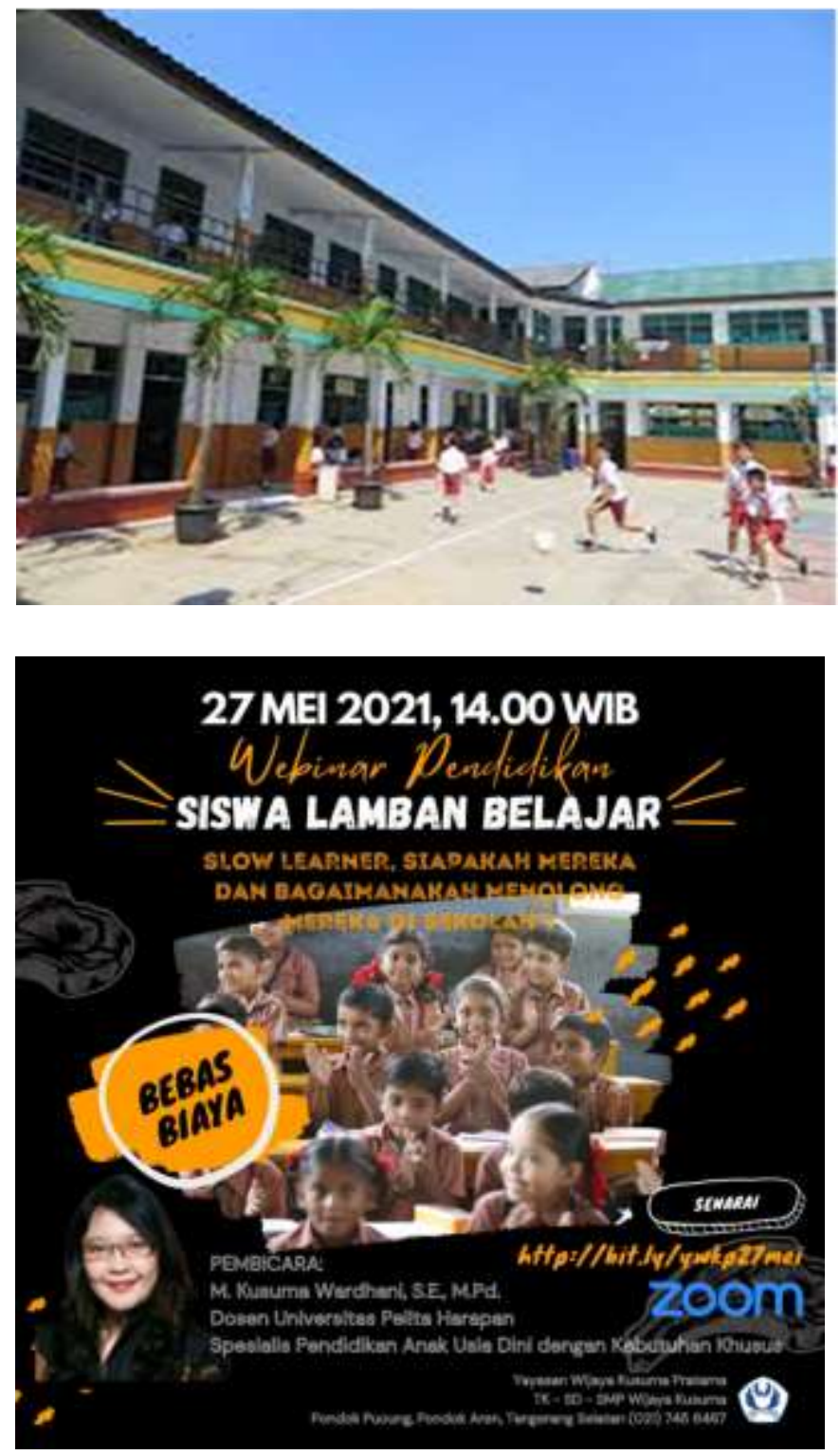

E-banner Webinar Pendidkan Siswa Lamban Belajar

Penulis adalah pengajar di Fakultas Pendidikan Universitas Pelita Harapan. Mata kuliah yang diajarkan adalah Pendidikan Luar Biasa, Pendidikan Anak Usia Dini , Pedagogi serta Belajar dan Mengajar. Sebelum melayani di UPH, penulis banyak bekerja di sektor pendidikan dan sosial di beberapa Lembaga Non Governmental International serta di salah satu badan United Nation ( UN OCHA) di Jakarta.

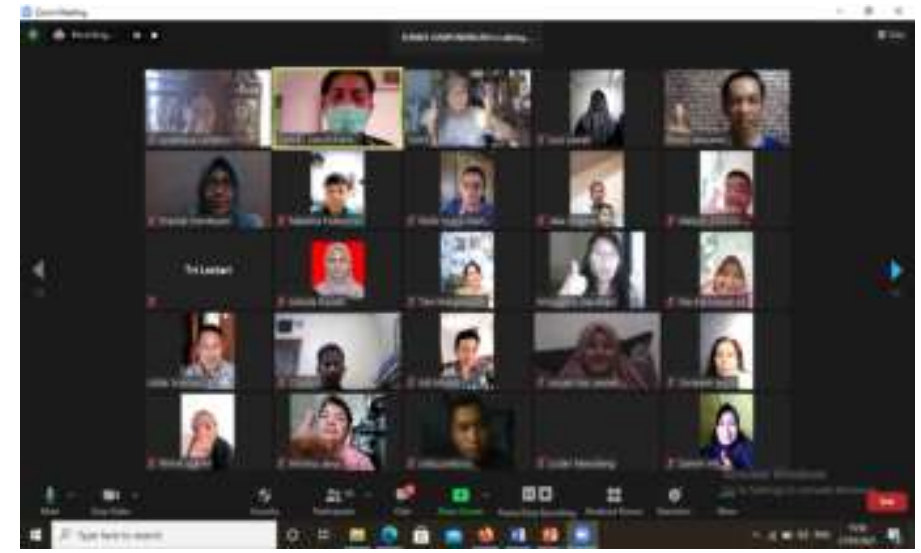

Tangkapan Layar Webinar Pendidikan Siswa Lamban Belajar 